Полішук В. В., polishykvolodumur@gmail.com,ORCID ID: 0000-0002-4404-2603, аспірант, Львівський торговельно-економічний університет, м. Львів

\title{
КОНЦЕПТУАЛЬНІ ХАРАКТЕРИСТИКИ МІГРАЦІЙНИХ ПРОЦЕСІВ ТА ЇХ ВПЛИВУ НА СОЦІАЛЬНО-ЕКОНОМІЧНИЙ РОЗВИТОК ДЕРЖАВИ
}

\begin{abstract}
Анотація. Мета статті полягає у науковому обтрунтуванні концептуальних характеристик міграційних проиесів та їх впливу на соиіально-економічний розвиток держави. Проведено історичний зріз аналізу практики та сприйняття міграчійних прочесів, починаючи від первісного суспільства і закінчуючи сучасними глобалізаційними тенденціями. Узагальнено поширені контексти досліджень міграчійних прочесів у сучасній вітчизняній науці міграчіологї̈ на стику галузей знань економіки, соиіологї̈, права та державного управління. Сформовано типові схеми нереалізованого і погашеного міграційного процесу. Зроблено висновок, щзо для сучасного глобалізованого світу залишаються поширеними односторонні міграційні процеси, які можуть передбачати повний циклл адаптації, інтеграції, натуралізаџії та асиміляції мігранта або ж зберігати диференичіацію інституту громадянства. Доведено, щчо зворотний міграційний процес, окрім регульованого, може бути добровільним - у випадку неуспішної адаптації або досягнення поставлених иілей (отримання певної суми доходу, знань, досвіду), і примусовим - у випадку вимушених заходів держави приймаючого суспільства. Наголошено, щуо однією з сучасних та актуальних схем міграційного процесу є реверсна. Виявлено, щуо держави в умовах відкритих кордонів основною метою регулювання міграційних процесів часто ставлять забезпечення ичиклічності міграції. Отримані відповідні результати дозволили визначити вплив (позитивний та негативний) міграційних прочесів на сочіально-економічний розвиток держави згідно з параметрами його забезпечення (економічне зростання, інвестиції, бізнес і самозайнятість, демографічне відтворення, ринки праці, соціальна інфраструктура, система соціального захисту, рівень і якість життя населення) та структурного розподілу (етапність, зміни людського потенціалу, правова визначеність, обсяги, динаміка, інтенсивність, час (періодичність), вектор (географія), територіальні суб'єкти, мета, причинність і наслідковість, потениійність та реалізованість, урегульованість).
\end{abstract}

Ключові слова: міграція, міграційний процес, соціально-економічний розвиток, суспільство, людський потенціал.

Polishchuk V. V., polishykvolodumur@gmail.com, ORCID ID: 0000-0002-4404-2603,

Postgraduate, Lviv University of Trade and Economics, Lviv

\section{CONCEPTUAL CHARACTERISTICS OF MIGRATION PROCESSES AND THEIR IMPACT ON THE SOCIO-ECONOMIC DEVELOPMENT OF THE COUNTRY}

\begin{abstract}
The purpose of the article is to scientifically substantiate the conceptual characteristics of migration processes and their impact on the socio-economic development of the state. A historical section of the analysis of the practice and perception of migration processes, starting from primitive society and ending with modern globalization trends is implemented. The widespread contexts of research of migration processes in the modern domestic science of migration at the junction of branches of knowledge of economics, sociology, law and public administration are generalized. Typical schemes of unrealized and repaid migration process are formed. It is concluded that for the modern globalized world unilateral migration processes remain widespread, which may involve a full cycle of adaptation, integration, naturalization and assimilation of the migrant or maintain the differentiation of the institution of citizenship. It is proved that the reverse migration process, in addition to the regulated one, can be voluntary - in case of unsuccessful adaptation or achievement of goals (obtaining a certain amount of income, knowledge, experience), and forced - in case of forced measures of the host society. It is emphasized that one of the modern and relevant schemes of the migration process is the reverse. It was found that in the conditions of open borders, the main goal of regulating migration processes is often to ensure the cyclical nature of migration. The obtained results allowed to determine the impact (positive and negative) of migration processes on the socio-economic development of the state according to the parameters of its provision (economic growth, investment, business and self-employment, demographic reproduction, labor markets, social infrastructure, social protection system, level and quality of life population) and structural distribution (stages, changes in human potential, legal certainty, volumes, dynamics, intensity, time (periodicity), vector (geography), territorial subjects, purpose, causality and consequence, potentiality and feasibility, settlement).
\end{abstract}

Keywords: migration, migration process, socio-economic development, society, human potential.

JEL Classification: F22, J61, O15

DOI: https://doi.org/10.36477/2522-1205-2021-64-11 
Постановка проблеми. Міграційні процеси в сучасних умовах глобалізації та зростаючої мобільності населення є актуальним об'єктом науковоприкладних досліджень, що потребує якісного теоретико-методичного супроводу. Висока динамічність змін та мінливість середовища сьогодення обумовлюють потребу перегляду актуальних підходів до державного регулювання міграційних процесів із урахуванням впливу на соціальноекономічний розвиток на різних просторових рівнях.

Аналіз останніх досліджень і публікацій. Поняття міграційних процесів є одним із основоположних у міграціології, що нині активно формується як наука про кількісно-якісні характеристики міграції та всі пов'язані 3 нею процеси. Термін "міграціологія" починає активно використовуватись у наукових працях українських учених (Т. Васильців, С. Гринкевич, О. Іляш, Я. Качмарик, М. Куницька-Іляш, О. Левицька, Р. Лупак, О. Мульська та ін.) зі спробами поглиблення його політико-правового напрямку. В зарубіжних джерелах використовується термін "migration studies" як міждисциплінарна галузь досліджень на стику антропології, історії доколоніального періоду ("prehistory"), історії, економіки, права, соціології та досліджень постколоніального періоду.

Постановка завдання. Метою статті є наукове обгрунтування концептуальних характеристик міграційних процесів та їх впливу на соціальноекономічний розвиток держави.

Виклад основного матеріалу дослідження. Еволюція людства, виникнення та активізація переміщень населення призвели до зміни характеру міграційних процесів та їхнього сприйняття (починаючи від первісного суспільства і закінчуючи сучасними глобалізаційними тенденціями). Якщо на етапах первісного суспільства міграційні процеси були вкрай обмеженими та здійснювалися на невеликі відстані з метою пошуку безпечних умов перебування, то на нинішньому етапі сприймаються як необхідність, право і безумовність (рис. 1).

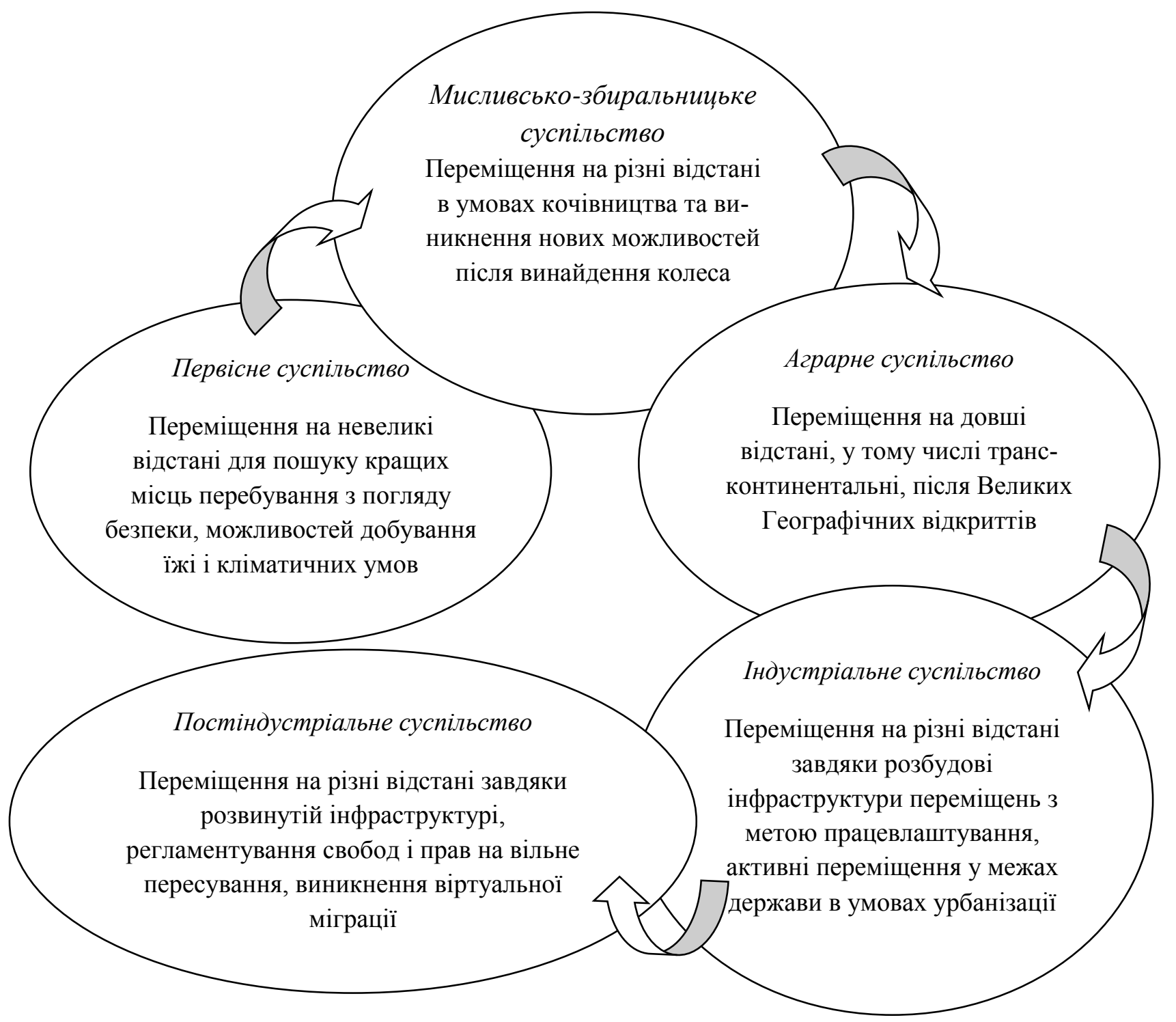

Рис. 1. Історичний зріз аналізу практики та сприйняття міграційних процесів 
Вісник Львівського торговельно-економічного університету. Економічні науки. № 64, 2021

Предметні напрямки аналізування міграційних процесів

Табличя 1

\begin{tabular}{|c|c|}
\hline $\begin{array}{l}\text { Предметні } \\
\text { напрямки }\end{array}$ & Автори \\
\hline Структурний & Характеристики міграційних процесів - комплексні (Е. Лібанова), часові (І. Майданік) \\
\hline Причинний & $\begin{array}{c}\text { Вплив на міграційні процеси глобалізації й інтеграції (О. Позняк, О. Риндзак), } \\
\text { геоекономічних трансформацій (К. Шиманська), трансформації ринків праці (У. Садова), } \\
\text { міжтериторіальної асиметрії (О. Корнієнко) }\end{array}$ \\
\hline Наслідковий & $\begin{array}{c}\text { Вплив міграційних процесів на різні сфери - сочіально-економічну (Т. Мельник, } \\
\text { К. Величко, Л. Носач, Ю. Курунова), працересурсну (3. Кобеля, Г. Смалійчук), освітню } \\
\text { (М. Романюк), політичну (С. Швець) }\end{array}$ \\
\hline Безпековий & $\begin{array}{c}\text { Тісний взаємозв’язок міграційних процесів з рівнем соціальної та економічної безпеки } \\
\text { (О. Сидорчук) }\end{array}$ \\
\hline Соціальний & $\begin{array}{c}\text { Особливості міграційних процесів для окремих соціальних груп (Г. Герасименко, } \\
\text { О. Мульска) }\end{array}$ \\
\hline Управлінський & $\begin{array}{c}\text { Міграційні процеси як об’єкт регулювання, функція державної політики (А. Шевцов, } \\
\text { О. Малиновська) }\end{array}$ \\
\hline
\end{tabular}

Разом зі зміною практики та сприйняття міграційних процесів формувалися міграційні теорії. Їхні положення важливі для розуміння причин, закономірностей та наслідків міграційних процесів, що є основою для наукового обгрунтування державного регулювання у даній сфері. Велика кількість міграційних теорій обумовила різні підходи до їхнього узагальнення: теорії, що обгрунтовують причини міграції на рівні особистості, і теорії, що обгрунтовують механізми міграції на рівні держави та в глобальних масштабах [1;2, с. 507-514; 3, с. 5058]; теорії, що пояснюють причини міграції, і теоpiï, що визначають закономірності “саморозвитку” міграції [4, с. 5-13; 5, с. 1-7].

Актуальність наукових досліджень міграційних процесів обумовила формування різних предметних напрямків у їх аналізуванні. У табл. 1 узагальнено поширені контексти досліджень міграційних процесів у сучасній вітчизняній науці міграціології на стику галузей знань економіки, соціології, права та державного управління.

Наслідковий предметний напрямок включає сочіально-економічний. Він передбачає дослідження впливу міграційних процесів на різні аспекти соціального та економічного характеру, що охоплюють сфери господарювання та життєдіяльності людини. Для цілісного розуміння особливостей дослідження міграційних процесів у контексті забезпечення соціально-економічного розвитку держави розглянемо здійснені напрацювання щодо змісту таких процесів та їх структурних характеристик.

Огляд наукових джерел 3 даного питання дозволяє зробити висновок, що, незважаючи на частоту використання терміна "міграційний процес", конкретизація його змісту наводиться рідко. Тобто у більшості досліджень автори використовують цей термін як безумовний і загальнозрозумілий, що не завжди є правильним.

Оскільки базовою характеристикою міграційного процесу є його етапи, розглянемо їхні $m u$ пові схеми, актуальні для обгрунтування моделей i методів державного регулювання в даній сфері для українського суспільства.

3 огляду на те, що міграційний процес включає формування потенціалу міграції, першою типовою схемою є “міграційний процес нереалізований" (рис. 2a). Це означає, що потенційний мігрант вчинив низку дій (збір інформації, вивчення можливостей), які не трансформували його підготовку до міграції в реальні переміщення. Причини цього можуть бути особистісні, пов'язані 3 ціннісним відторгненням чи впливом ближчого соціального оточення. 
Herald of Lviv University of Trade and Economics. Economic Sciences. № 64, 2021

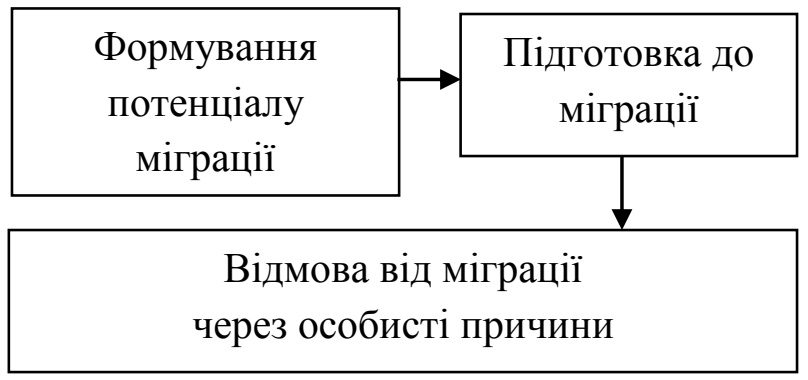

а) Міграційний процес нереалізований

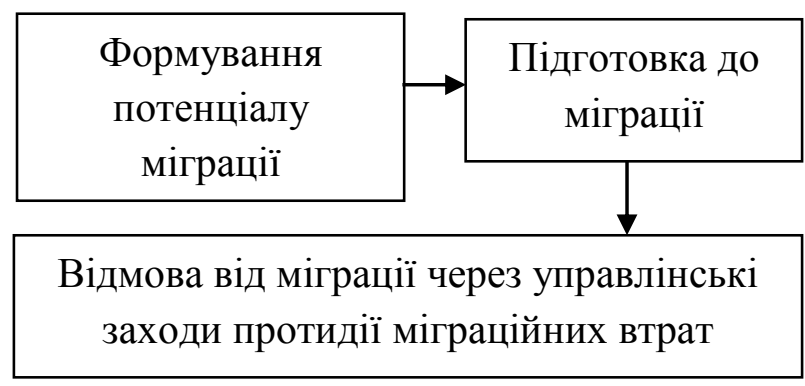

б) Міграційний процес погашений (нівельований)

Рис. 2. Типові схеми нереалізованого і погашеного міграційного процесу

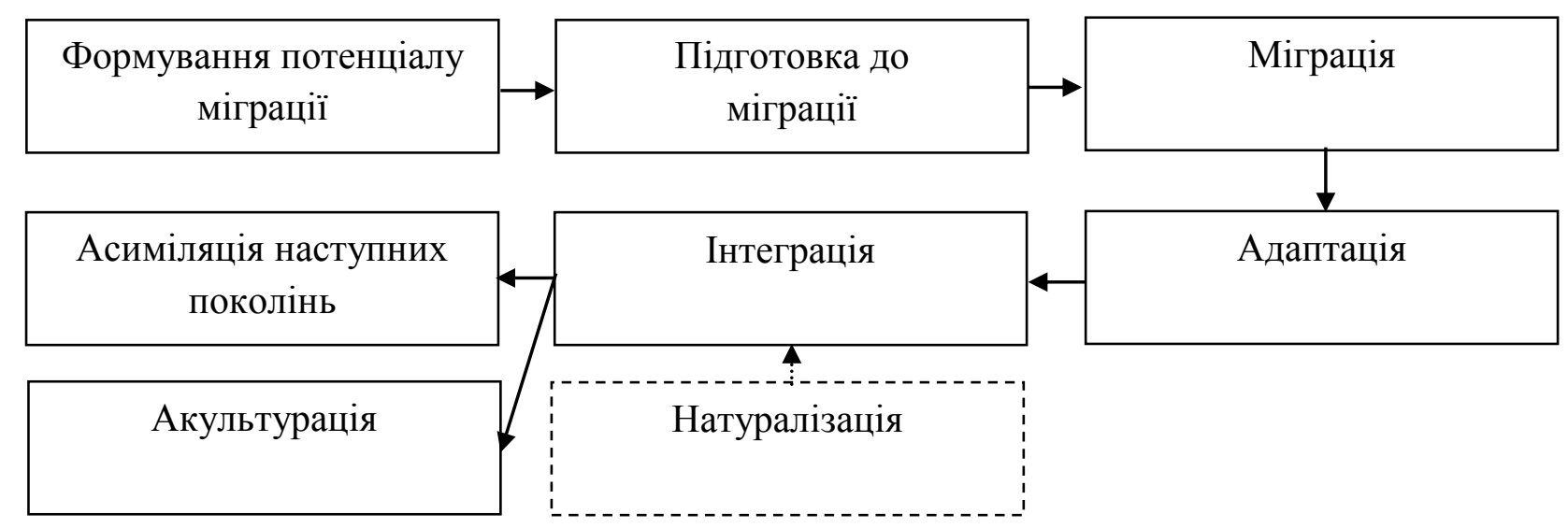

Рис. 3. Типова схема одностороннього міграційного процесу з набуттям / без набуття громадянства

"Міграиійний прочес погашений (нівельований)" (рис. 2б) означає, що потенційний мігрант вчиняв дії щодо збору інформації, однак з боку управлінських суб'єктів (органів державної чи місцевої влади) відбулися заходи, спрямовані на стримування переміщень чи їх заборону (протидія міграційних втрат). Заходами стримування можуть бути підвищення соціальних стандартів щодо оплати праці, створення нових робочих місць, покращення умов кредитування, соціального захисту і т. д. За таких обставин особа приймає рішення, що можливі ризики внаслідок переміщення не будуть достатньою мірою компенсовані.

Для сучасного глобалізованого світу залишаються поширеними односторонні міграційні процеси, які можуть передбачати повний цикл адаптації, інтеграції, натуралізації та асиміляції мігранта або ж зберігати диференціацію інституту громадянства. Залежно від концепції державного регулювання міграційних процесів влада приймаючого суспільства може проводити політику натуралізації, чому передує або ситуативна боротьба 3 нелегальною міграцією, або послідовний процес адаптації й інтеграції мігрантів у приймаюче суспільство (рис. 3).

Науковці міграціологічних питань по-різному підходять до виділення етапів та форм адаптації, часто включаючи іiі до інтеграції. На наш погляд, це дещо різні процеси. Адаптація є процесом початкового розуміння мігрантом особливостей приймаючого суспільства. На даному етапі, як правило, особа-мігрант, очікуючи надалі на певні вигоди, отримує так звані “неекономічні" втрати (noneconomic losses), пов'язані зі зміною місця, що кидають виклик поняттю успішної адаптації [6, с. $150-155 ; 7$, с. $627-630]$.

У випадку успішного прийняття мігрантом особливостей суспільства-реципієнта відбувається його інтеграція. Інтеграція мігрантів для демократичних держав $є$ складним процесом, оскільки вимагає двостороннього залучення - не лише особамігрант має приймати реалії нового способу життя, але й приймаюче суспільство має бути відкритим для культурного збагачення [8, с. 1-5; 9, с. 67-72].

Активні осібні міграційні процеси у сучасному світі супроводжуються зростанням сімейної міграції. У зв'язку з цим необхідно окремо виділити типову схему одностороннього міграційного процесу домогосподарства (рис. 4). Міграція домогосподарств в умовах зростаючої мобільності населення постає актуальним об'єктом у регулюванні міграційних процесів для більшості міграційно активних держав.

Міграційний процес домогосподарств часто $€$ результатом успішної адаптації одного 3 його членів та подальшого залучення інших. Протилежним випадком може бути виїзд особи з формуванням сім’ї вже за кордоном. У такій ситуації процеси асиміляції відбуватимуться швидше, однак наслідки втрат для суспільства походження виявляться нижчими, ніж у випадку виїзду всієї сім’ї та народження дітей за новим місцем проживання [10, c. 53-55]. 
Вісник Львівського торговельно-економічного університету. Економічні науки. № 64, 2021

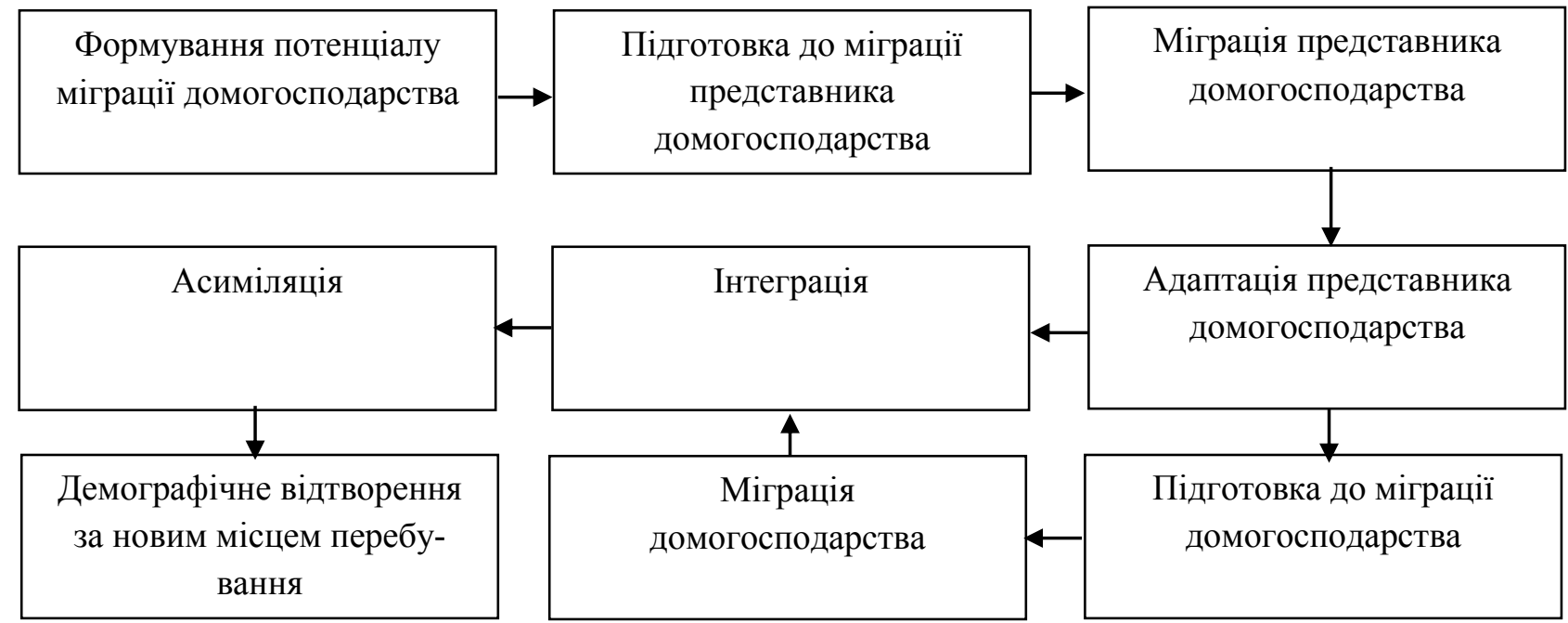

Рис. 4. Типова схема одностороннього міграційного процесу домогосподарства

Розглянуті вище типові схеми відображають міграційні втрати. Розуміючи права і свободи переміщень сучасної людини, практично всі держави забезпечують їх реалізацію у визначеному правовому режимі, однак застосовують при цьому різні методи стимулювання повернення осіб з міграційним досвідом, ефективне залучення міграційного капіталу в місцеву економіку. Таким чином, виникає зворотний регульований міграційний прочес.

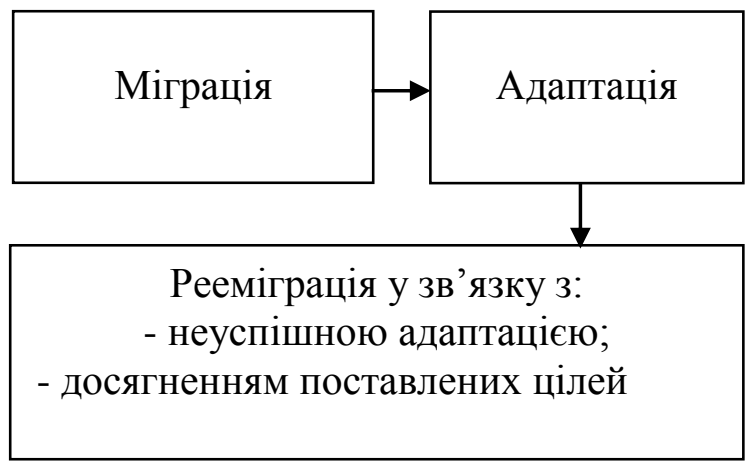

а) Міграційний процес добровільний
Зворотний міграчійний прочес, окрім регульованого, може бути добровільним - у випадку неуспішної адаптації або досягнення поставлених цілей (отримання певної суми доходу, знань, досвіду), і примусовим - у випадку вимушених заходів держави приймаючого суспільства (рис. 5).

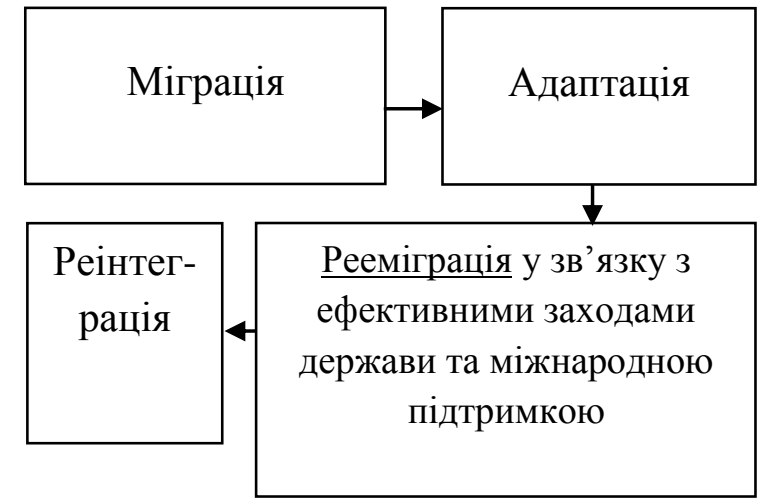

б) Міграційний процес регульований

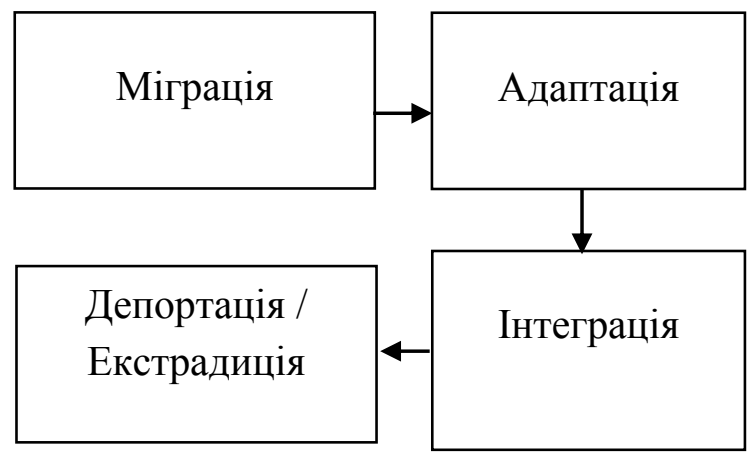

в) Міграційний процес примусовий

Рис. 5. Типові схеми зворотного міграційного процесу 


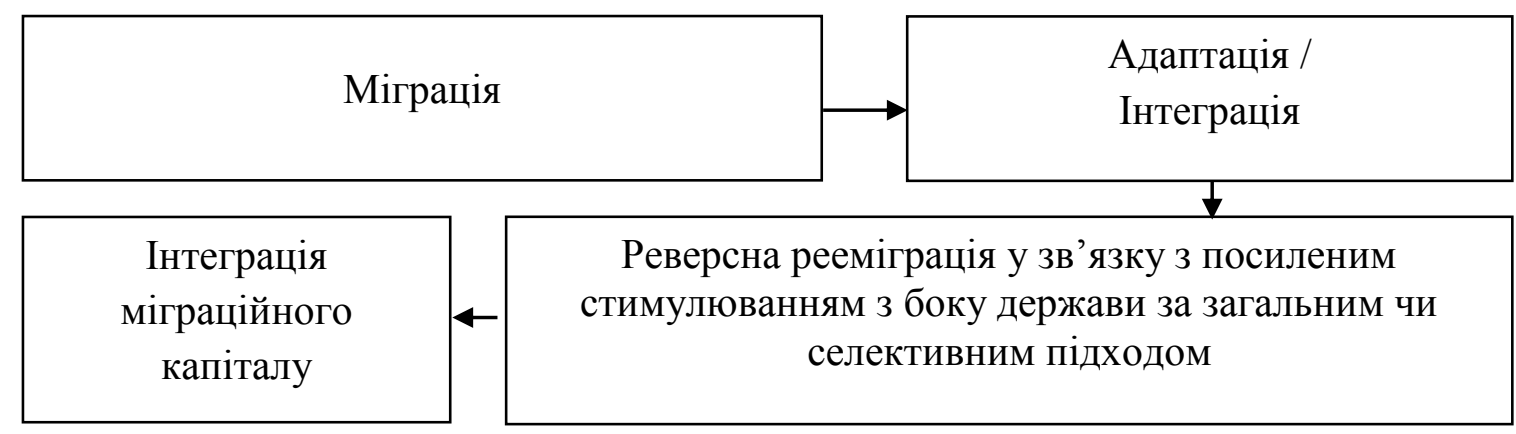

Рис. 6. Типова схема реверсного міграційного процесу

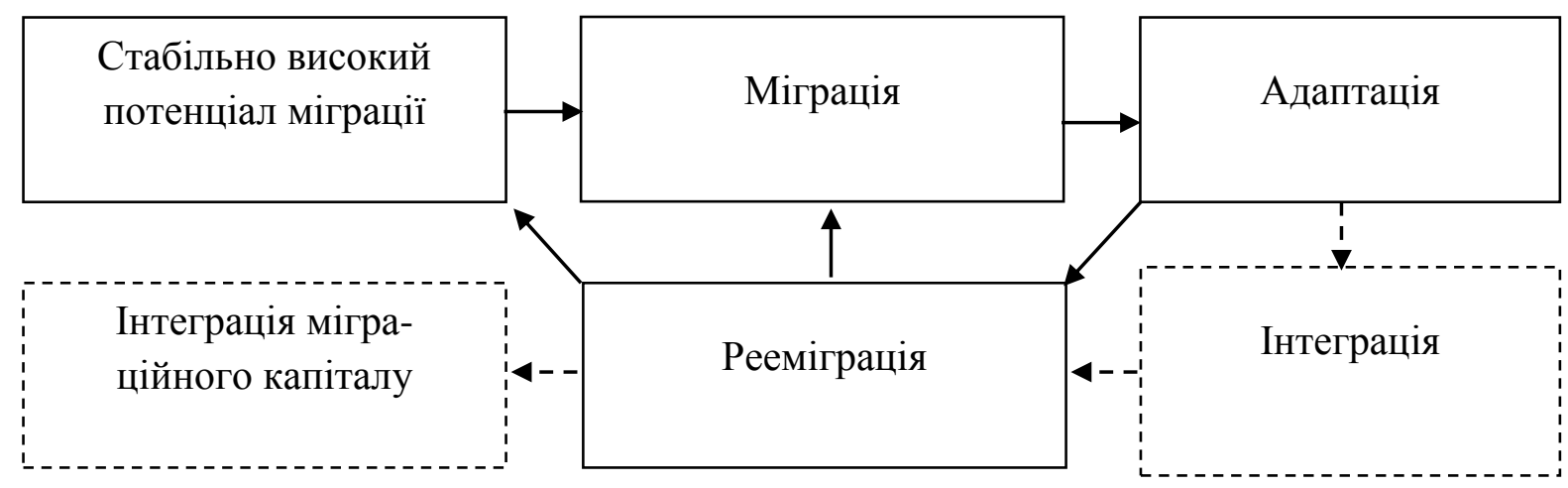

Рис. 7. Типова схема циклічного міграційного процесу

Однією 3 сучасних та актуальних схем міграційного процесу є реверсна. Реверсний міграційний процес спричинений цільовим стимулюванням рееміграції, що, як правило, після настання міграційної хвилі обмежений у часі та супроводжується застосуванням дієвих стимуляторів. Це може бути потужна урядова програма рееміграції зі спрямованістю на всіх мігрантів або осіб, що відповідають певним критеріям - віку, економічної активності, кваліфікації, професії, готовності інвестувати в бізнес тощо (рис. 6).

Сучасні держави, які розвиваються в умовах відкритих кордонів, основною метою регулювання міграційних процесів часто ставлять забезпечення циклічності міграції. Циклічний міграційний процес $\epsilon$ ознакою домінування короткострокової (у тому числі маятникової) і сезонної міграції (рис. 7).

Переважання такої схеми міграційних процесів означає, що суспільство розвивається в умовах високого рівня мобільності людських ресурсів. Циклічність міграції до пандемії Covid-19 стала звичним явищем для соціально-економічного розвитку багатьох суспільств, особливо тих, які формують міждержавні інтеграційні утворення 3 розвинутою інфраструктурою переміщень. Циклічність міграції здійснює значний вплив на усі процеси:

- на рівні держав та регіонів призводить до формування міждержавних та між (транс) регіональних ринків праці, освітніх систем, споживчих ринків;

- на рівні домогосподарств та осіб призводить до зміни способу життя та сприйняття міграції як умови підвищення якості життя (концепція міграції способу життя, розроблена англійськими вченими К. Орелі та М. Бенсоном [11, с. 20-37]).

Циклічні міграційні процеси характерні, як правило, для прикордонних регіонів, що розвиваються в умовах соціально-економічної асиметрії, a також для невеликих держав зі специфічною спеціалізацією економіки (OAE, Сінгапур, Монако, Ліхтенштейн, Люксембург, Швейцарія та ін.).

Варіативність схем міграційних процесів у залежності від виокремлених етапів визначає необхідність формування системи державного регулювання у даній сфері з підбором методів впливу залежно від ситуації. Основою цього є з'ясування різних характеристик міграційних процесів, серед яких виокремлено наслідковість. Одним із фокусів дослідження наслідковості міграційних процесів $€$ соціально-економічний. Він дозволяє виявити: яким чином міграційні процеси впливають на соціальноекономічний розвиток; яким чином можна оптимізувати вплив міграційних процесів на соціально-економічний розвиток, у тому числі за різними параметрами, рівнями, суб'єктами; яким чином через стимулювання соціально-економічного розвитку можна регулювати міграційні процеси та чи це потрібно взагалі у випадку, якщо міграційні детермінанти сприяють позитивним тенденціям $[12$, c. $105-110 ; 13$, с. $1677-1681]$.

Соціально-економічний розвиток $\epsilon$ певною мірою антагоністичною категорією, оскільки поєднує в собі економічні, орієнтовані на прибуток, та соціальні, орієнтовані на людину й екологію, процеси. Сочіально-економічний розвиток - це 
вектор системних змін, базований на узгодженні економічних (комерціалізованих) і соціальних (людиноорієнтованих, екологозахисних) цілей та інтересів, що забезпечує покращення якості життя населення та ефективізацію використання природно-ресурсних і виробничих можливостей на інноваційних засадах.

Дослідження міграційних процесів 3 погляду впливу на соціально-економічний розвиток потребує поглиблення теоретико-методичних підходів. Зазвичай фахівці і науковці акцентують увагу на проблемі недосконалої соціальної та економічної державної політики щодо вирішення численних проблем, пов'язаних із міграцією. Натомість розробка цілісних підходів до оцінювання впливу міграційних процесів на соціально-економічний розвиток України має вибірковий характер [15, с. 169-179]. Оскільки українське суспільство вже тривалий період часу розвивається як міграційно активне, актуально досліджувати вплив міграційних процесів на економіку, інвестиційну сферу, бізнес і самозайнятість, демографічне відтворення, ринки праці, сфери освіти, охорони здоров'я, культури, соціальну інфраструктуру, систему соціального захисту, рівень і якість життя населення тощо (табл. 2). Комплекс таких індикаторів визначає пріоритети державного регулювання міграційних процесів, базованих на оцінюванні середовищних передумов їх формування та розвитку $[14$, с. $323-$ 327].

У табл. 3 відображено, як структурні ознаки міграційних процесів впливають на соціальноекономічний розвиток. Такі впливи відображаються у факторних (людський потенціал як фактор виробництва), працересурсних, кваліфікаційних, іміджевих, інтеграційних, безпекових характеристиках.

Вплив міграційних процесів на соціально-економічний розвиток держави

\begin{tabular}{|c|c|c|}
\hline \multirow{2}{*}{$\begin{array}{c}\text { Параметри } \\
\text { соціально-економічного } \\
\text { розвитку }\end{array}$} & \multicolumn{2}{|c|}{ Вплив міграційних процесів } \\
\hline & негативний & позитивний \\
\hline $\begin{array}{l}\text { Економічне } \\
\text { зростання }\end{array}$ & $\begin{array}{c}\text { Втрати людського фактора виро- } \\
\text { бництва з можливістю інноватизації } \\
\text { економічних процесів }\end{array}$ & $\begin{array}{c}\text { Додатковий попит на } \\
\text { внутрішньому споживчому ринку за } \\
\text { рахунок міграційних доходів }\end{array}$ \\
\hline Інвестиції & $\begin{array}{c}\text { Домінування пасивних } \\
\text { (споживчих) інвестицій з низькою } \\
\text { віддачею }\end{array}$ & $\begin{array}{c}\text { Залучення міграційних доходів } \\
\text { у формі активних інвестицій }\end{array}$ \\
\hline $\begin{array}{c}\text { Бізнес і } \\
\text { самозайнятість }\end{array}$ & $\begin{array}{l}\text { Дефіцит робочих кадрів на ринках } \\
\text { праці міграційно активних територій }\end{array}$ & $\begin{array}{c}\text { Залучення міграційного капіта- } \\
\text { лу (доходів, досвіду, знань) у ре- } \\
\text { алізацію проектів }\end{array}$ \\
\hline $\begin{array}{l}\text { Демографічне } \\
\text { відтворення }\end{array}$ & $\begin{array}{c}\text { Втрати демографічного потен- } \\
\text { ціалу, низька народжуваність уна- } \\
\text { слідок міграції жінок фертильного } \\
\text { віку, поширення практики народжен- } \\
\text { ня за кордоном } \\
\end{array}$ & $\begin{array}{l}\text { Зниження рівня навантаження } \\
\text { на соціальну інфраструктуру }\end{array}$ \\
\hline Ринки праці & $\begin{array}{c}\text { Низька конкуренція на ринках } \\
\text { праці } з \text { демотивацією розвитку особи- } \\
\text { стого потенціалу }\end{array}$ & $\begin{array}{c}\text { Зниження рівня навантаження } \\
\text { на ринки праці (нижчі безробіття, } \\
\text { витрати на фонд оплати праці) }\end{array}$ \\
\hline $\begin{array}{c}\text { Соціальна } \\
\text { інфраструктура }\end{array}$ & $\begin{array}{c}\text { Низький попит на послуги та } \\
\text { зниження їхньої якості } \\
\text { Втрати інвестицій у підготовку } \\
\text { фахівців і робітничих кадрів }\end{array}$ & $\begin{array}{c}\text { Стимулювання конкуренції з } \\
\text { пропозицією якісних і конкуренто- } \\
\text { спроможних послуг (освітніх, } \\
\text { медичних, транспортних і т. д.) }\end{array}$ \\
\hline $\begin{array}{l}\text { Система соціального } \\
\text { захисту }\end{array}$ & $\begin{array}{c}\text { Дефіцит мобілізованих фінансо- } \\
\text { вих ресурсів в умовах втрат працез- } \\
\text { датного населення }\end{array}$ & $\begin{array}{r}\text { Вище пенсійне забезпечення } \\
\text { населення за рахунок страхового } \\
\text { стажу, набутого за кордоном }\end{array}$ \\
\hline $\begin{array}{l}\text { Рівень і якість життя } \\
\text { населення }\end{array}$ & $\begin{array}{c}\text { Поглиблення соціально- } \\
\text { економічної нерівності між різними } \\
\text { групами населення }\end{array}$ & $\begin{array}{c}\text { Можливості забезпечення гід- } \\
\text { ного рівня та якості життя завдяки } \\
\text { міграції }\end{array}$ \\
\hline
\end{tabular}




\section{Herald of Lviv University of Trade and Economics. Economic Sciences. № 64, 2021}

Таблиияя 3

Вплив структурних ознак міграційних процесів на соціально-економічний розвиток держави

\begin{tabular}{|c|c|c|}
\hline \multirow{2}{*}{$\begin{array}{c}\text { Структурні ознаки } \\
\text { міграційних процесів }\end{array}$} & \multicolumn{2}{|c|}{ Вплив на соціально-економічний розвиток } \\
\hline & Негативний & Позитивний \\
\hline Етапність & $\begin{array}{c}\text { Втрати людського потенціалу при низькому } \\
\text { рівні циркулюючих міграційних процесів }\end{array}$ & $\begin{array}{l}\text { Зростаючий міграційний капітал із можливістю } \\
\text { його інвестування при циркулюючій міграції }\end{array}$ \\
\hline $\begin{array}{c}\text { Зміни людського } \\
\text { потенціалу }\end{array}$ & $\begin{array}{c}\text { Втрати інтелектуально-трудового потенціалу за } \\
\text { умови низькокваліфікованої міграції }\end{array}$ & $\begin{array}{c}\text { Розвиток інтелектуально-трудового потенціалу } \\
\text { за умов здобуття нових знань і досвіду }\end{array}$ \\
\hline Правова визначеність & $\begin{array}{c}\text { Негативний міжнародний імідж держави як } \\
\text { донора людських ресурсів } 3 \text { низькою правовою } \\
\text { культурою та схильністю до нелегальної } \\
\text { (незахищеної) міграції }\end{array}$ & $\begin{array}{c}\text { Інтеграція у міжнародний мобільний простір, } \\
\text { обмін досвідом і знаннями за умов легальної } \\
\text { (захищеної) міграції }\end{array}$ \\
\hline Обсяги & $\begin{array}{l}\text { Втрати людського потенціалу при надмірних } \\
\text { обсягах }\end{array}$ & $\begin{array}{c}\text { Конкурентний перерозподіл людського потен- } \\
\text { ціалу при регульованій міграції }\end{array}$ \\
\hline Динаміка, інтенсивність & $\begin{array}{c}\text { Кризові детермінанти в умовах міграційних } \\
\text { хвиль }\end{array}$ & $\begin{array}{c}\text { Послаблення тиску на внутрішню економіку і } \\
\text { ринок праці в умовах кризових коливань }\end{array}$ \\
\hline Час, періодичність & $\begin{array}{l}\text { Безповоротні втрати людського потенціалу в } \\
\text { умовах довгострокової, пожиттєвої міграції }\end{array}$ & $\begin{array}{c}\text { Можливості інтеграції міграційного капіталу в } \\
\text { умовах циркулюючих міграційних процесів }\end{array}$ \\
\hline Вектор, географія & $\begin{array}{c}\text { Утворення потужних міграційних мереж і си- } \\
\text { стем із впливом на реалізацію потенціалу } \\
\text { міграції інших осіб }\end{array}$ & $\begin{array}{l}\text { Конкурентний міжрегіональний перерозподіл } \\
\text { людського потенціалу завдяки переорієнтації } \\
\text { міграційних процесів із зовнішніх на внутрішні }\end{array}$ \\
\hline Територіальні суб’єкти & $\begin{array}{c}\text { Утвердження статусу донорства людського } \\
\text { потенціалу }\end{array}$ & $\begin{array}{c}\text { Розвиток міждержавних, } \\
\text { між(транс)регіональних соціально-економічних } \\
\text { просторів на взаємовигідних засадах }\end{array}$ \\
\hline Мета & $\begin{array}{l}\text { Втрати людського потенціалу в окремих сег- } \\
\text { ментних групах (молоді - при освітніх меті, } \\
\text { економічно активного населення - трудовій }\end{array}$ & $\begin{array}{c}\text { Розуміння пріоритетів внутрішнього розвитку } 3 \\
\text { покращенням соціально-економічних умов }\end{array}$ \\
\hline $\begin{array}{l}\text { Причинність і } \\
\text { наслідковість }\end{array}$ & $\begin{array}{l}\text { Довгострокові втрати людського потенціалу в } \\
\text { умовах інтелектуалізації міграційних процесів }\end{array}$ & $\begin{array}{c}\text { Розуміння пріоритетів внутрішнього розвитку } \\
\text { для регулювання потенціалу міграційних про- } \\
\text { цесів }\end{array}$ \\
\hline $\begin{array}{c}\text { Потенційність } v s \\
\text { реалізованість }\end{array}$ & $\begin{array}{c}\text { Інституціоналізація високого рівня реалізації } \\
\text { потенціалу міграційних процесів }\end{array}$ & $\begin{array}{c}\text { Визначення конкурентних переваг середовища } \\
\text { збереження людського потенціалу }\end{array}$ \\
\hline Регульованість & $\begin{array}{c}\text { Низькі ефективність державного управління і } \\
\text { політична культура без стратегічного бачення } \\
\text { соціально-економічного розвитку }\end{array}$ & $\begin{array}{c}\text { Ситуативне реагування держави на структурні } \\
\text { ознаки міграційних процесів із нівелюванням їх } \\
\text { потенціалу при потребі }\end{array}$ \\
\hline
\end{tabular}

Висновки i перспективи подальших досліджень у даному напрямі. Міграційні процеси все більше визначають темпи соціальноекономічного розвитку держави та здатні забезпечити значні конкурентні переваги економіки на міжнародному рівні. Здатність держави сформувати необхідний інтелектуальний капітал значною мірою залежить від міграційної активності населення, що повинна бути збалансованою та враховувати належним чином інтереси економіки. Виходячи 3 таких тверджень, вдалося виявити низку характеристик, у яких вказуються еволюційні тенденції міграційних процесів та їх функціональноструктурний вплив (позитивний та негативний) на соціально-економічний рівень зростання держави.

Перспективою дослідження слід розглядати виявлення взаємозв'язків між соціальноекономічними результатами міграційних процесів та умовами і чинниками, що визначають їх обсяги та темпи зростання.

\section{ЛITEРАТУРА}

1. Вербовий М. В. Доктринальні засади міжнародної трудової міграції / Вербовий М. В. // Демократичне врядування. - 2011. - Вип. 7 [Елек- тронний ресурс]. - Режим доступу: http://nbuv.gov.ua/UJRN/DeVr_2011_7_9.

2. Modelling the Conditions Affecting Population Migration Activity in the Eastern European Region: The Case of Ukraine / Levytska O., Mulska O., Ivaniuk U., Vasyltsiv T., Lupak R., Kunytska-Iliash M. // Tem Journal. - 2020. - Vol. 9. - № 2. - P. 507-514.

3. Vasyltsiv T. G. Social Security of Ukraine and the EU: aspects of convergence and improvement of migration policy / Vasyltsiv T. G., Lupak R. L., Kunytska-Iliash M. V. // Baltic Journal of Economic Studies. - 2019. - Vol. 5. - № 4. - P. 50-58.

4. Безуглий П. Г. Теоретичні засади дослідження міграційних процесів / Безуглий П. Г. // Політичне життя. - 2018. - № 1. - С. 5-13.

5. Innovative development of human capital in the conditions of globalization / Kuzmin O., Bublyk M., Shakhno A., Korolenko O., Lashkun H. // E3S Web of Conferences. - 2020. - Vol. 166, 13011. - P. 1-7.

6. Instruments of regional policy for human resources conservation by means of regulation of external youth migration of rural territories of the Carpathian region / Vasyltsiv T., Lupak R., Kunytska-Iliash M., Levytska O., Mulska O. // Agricultural and Resource Economics. - 2020. - Vol. 6. - № 3. - P. 149-170. 
7. Migration as Adaptation? / Vinke K., Bergmann J., Blocher J., Upadhyay H., Hoffmann R. // Migration Studies. - 2020. - Vol. 8. Is. 4. - P. 626-634.

8. Migration: theory, research and practice in guidance and counselling / Hughes D., Akkök F., Arulmani G., Zelloth H. // British Journal of Guidance \& Counselling. - 2019. - Vol. 47. - P. 1-5.

9. Гринкевич С. С. Формування системи та структурування інституційного забезпечення реалізації державної політики розвитку i використання трудового потенціалу України / Гринкевич С. С., Лупак Р. Л., Васильків Ю. В. // Бізнес Інформ. - 2015. - № 7. - С. 67-72.

10. Іляш О. І. Негативні наслідки міжнародної міграції людських ресурсів за умови формування в Україні зони вільної торгівлі / Іляш О. І. // Журнал європейської економіки. - 2017. Т. 8. - Вип. 1. C. $50-59$.

11. Benson M. From lifestyle migration to lifestyle in migration: Categories, concepts and ways of thinking / Benson M., Reilly K. // Migration Studies. 2016. -Vol. 4. Is. 1. - P. 20-37.

12. Качмарик Я. Д. Система рішень процесу відтворення трудового потенціалу корпоративних систем / Качмарик Я. Д., Лупак Р. Л. // Обліковоаналітичні системи суб'єктів господарської діяльності в Україні. - 2005. - Спец. вип. 15 (Ч. 1). C. 105-110.

13. Adoption of management decisions regarding the equalization of territorial asymmetry of demographic development of quality of life of the population / Turchyn L., Sobko O., Boichyk I., Zaverbnyj A., Shushpanov D. // Journal of Advanced Research in Dynamical and Control Systems. - 2020. - Vol. 12. - P. 1677-1681.

14. Лупак Р. Л. Вибір стратегічних напрямів забезпечення продуктивності та ефективності праці / Лупак Р. Л. // Економічний аналіз. - 2012. - Вип. 10. Ч. 3. - С. 323-327.

15. Васильців Т. Г. Сучасний стан та ризик розвитку ринку праці України у контексті соціальної безпеки в умовах євроінтеграції / Васильців Т. Г., Іляш О. І. // Журнал європейської економіки. - 2017. - № 9(2). - С. 169-179.

\section{REFERENCES}

1. Verbovyy, M. V. (2014), Doktrynal'ni zasady mizhnarodnoyi trudovoyi mihratsiyi, Demokratychne vryaduvannya, № $7, \quad$ available at: http://nbuv.gov.ua/UJRN/DeVr_2011_7_9.

2. Levytska O., Mulska O., Ivaniuk U., Vasyltsiv T., Lupak R. and Kunytska-Iliash M. (2020), Modelling the Conditions Affecting Population Migration Activity in the Eastern European Region: The Case of Ukraine, Tem Journal, vol. 9, № 2, p. 507-514.

3. Vasyltsiv, T. G., Lupak, R. L. and KunytskaIliash, M. V. (2019), Social Security of Ukraine and the EU: aspects of convergence and improvement of migration policy, Baltic Journal of Economic Studies, vol. 5, № 4, p. 50-58.
4. Bezuhlyy, P. H. (2018), Teoretychni zasady doslidzhennya mihratsiynykh protsesiv, Politychne zhyttya, № 1, p. 5-13.

5. Kuzmin O., Bublyk M., Shakhno A., Korolenko O. and Lashkun H. (2020), Innovative development of human capital in the conditions of globalization, E3S Web of Conferences, vol. 166, 13011, p. 1-7.

6. Vasyltsiv T., Lupak R., Kunytska-Iliash M., Levytska O. and Mulska O. (2020), Instruments of regional policy for human resources conservation by means of regulation of external youth migration of rural territories of the Carpathian region, Agricultural and Resource Economics, vol. 6, № 3, p. 149-170.

7. Vinke K., Bergmann J., Blocher J., Upadhyay H. and Hoffmann R. (2020), Migration as Adaptation? Migration Studies, vol. 8, Is. 4, p. 626-634.

8. Hughes D., Akkök F., Arulmani G. and Zelloth H. (2019), Migration: theory, research and practice in guidance and counseling, British Journal of Guidance \& Counselling, vol. 47, p. 1-5.

9. Hrynkevych, S. S. Lupak, R. L. and Vasyl'kiv, YU. V. (2015), Formuvannya systemy ta strukturuvannya instytutsiynoho zabezpechennya realizatsiyi derzhavnoyi polityky rozvytku i vykorystannya trudovoho potentsialu Ukrayiny, Biznes Inform, № 7, p. 67-72.

10. Ilyash, O. I. (2017), Nehatyvni naslidky mizhnarodnoyi mihratsiyi lyuds'kykh resursiv za umovy formuvannya v Ukrayini zony vil'noyi torhivli, Zhurnal yevropeys'koyi ekonomiky, T. 8, vyp. 1, p. 5059.

11. Benson M. and Reilly K. (2016), From lifestyle migration to lifestyle in migration: Categories, concepts and ways of thinking, Migration Studies, vol. 4, Is. 1, p. 20-37.

12. Kachmaryk, YA. D. and Lupak, R. L. (2005), Systema rishen' protsesu vidtvorennya trudovoho potentsialu korporatyvnykh system, Oblikovo-analitychni systemy subyektiv hospodars'koyi diyal'nosti v Ukrayini, Spets. № 15 (1), p. 105-110.

13. Turchyn L., Sobko O., Boichyk I., Zaverbnyj A. and Shushpanov D. (2020), Adoption of management decisions regarding the equalization of territorial asymmetry of demographic development of quality of life of the population, Journal of Advanced Research in Dynamical and Control Systems, vol. 12, p. 1677 1681.

14. Lupak, R. L. (2012), Vybir stratehichnykh napryamiv zabezpechennya produktyvnosti ta efektyvnosti pratsi, Ekonomichnyy analiz, № 10 (3), p. 323 327.

15. Vasyltsiv, T. H. and Ilyash, O. I. (2017), Suchasnyy stan ta ryzyk rozvytku rynku pratsi Ukrayiny v konteksti sotsial'noyi bezpeky v umovakh yevrointehratsiyi. Zhurnal yevropeyskoyi ekonomiky, 9(2), p. 169-179.

Стаття надійшла до редакції 6 липня 2021 року 